\title{
SYED MUHAMMAD NAQUIB AL-ATTAS DAN KONSEP METAFISIK DALAM ISLAM ${ }^{*}$
}

\author{
Akhmad Rofii Damyati** \\ Dosen STIU (Sekolah Tinggi IlmuUsuluddin) \\ Al Mujtama' Pamekasan \\ Email: masdimyati@gmail.com
}

\begin{abstract}
Abstrak:
Tulisan ini bertujuan menelisik aspek-aspek pandangan metafisis al-Attas tentang filsafat. Yaitu merangkumi interpretasinya mengenai konsep metafisik dari sudut pandang Islam yang merupakan harmonisasi dari tiga rumpun tradisi keilmuan dalam Islam, yaitu tradisi filsafat, tradisi Kalam dan tradisi Tasawwuf. Bisa disimpulkan bahwa tulisan ini mendiskusikan bagaimana metafisik dalam Islam lebih menyeluruh bila dibandingan dengan tradisi-tradisi lain yang juga mengonseptualisasikan metafisik.
\end{abstract}

Kata kunci: Al-Attas; metafisik; hakekat; ontologi; eksistensi; kuiditas; esensi; cara pandang Islam.

Abstract:

This paper is intended to provide insight into aspects of al-Attas' metaphysical view on philosophy. It will summarize his interpretation of the concept of metaphysics from Islamic point of view that is harmonized from three traditions of knolwedge in Islam, i.e. philosophy tradition, theology tradition and mystics tradition. Finally, it will discuss how metaphysics in Islam more comprehensive than other traditions which also conceptualize the metaphysics.

Keywords: Al-Attas; metaphyisics; hạaiiqah; ontology; existence; quiddity; essence; Islamic Worldview.

Prolog

Dalam sejarah pemikiran Islam, di antara obyek studi yang paling hangat dan dinamis adalah masalah metafisik. Bisa diklaim, obyek ini termasuk yang paling istimewa dalam filsafat Islam. Sebab para filosof Muslim sangat detail menjelaskan problem-problem yang muncul serta menyelesaikannya secara bijaksana. Sebagaimana diketahui, tema-tema

\footnotetext{
* Tulisan ini adalah adalah paper yang dipresentasikan pada Doktora Semineri per tanggal 08.05.2015 di İlahiyat Fakültesi Seminar Salonu 1t.1, Süleyman Demirel Üniversitesi, Türkiye, dengan judul "Nakip El-Attas'ın Felsefe Düşüncesinde Metafizik Kavramı”.

${ }^{* *}$ Kandidat doktor dalam bidang Filsafat Islam di Süleyman Demirel Üniversitesi, Türkiye.
} 
filsafat musti bermula dari isu metafisik. Sebab sebelum mengkaji tematema lain, menyelesaikan persoalan "ada", sebagai isu sentral dalam metafisik, perlu didahulukan. Serentetan pertanyaan tentang ada ini tidak boleh terlewatkan untuk dijawab tuntas, seperti: jika dikatakan sesuatu itu "ada", lantas 'bagaimana ia ada', 'dari mana munculnya', keberadaannya sejak kapan bermula dan kapan berakhir', 'sebab keberadaannya apa', 'adanya itu tunggal atau ada jenis-jenisnya', 'jika bukan tunggal, lalu suatu yang ada itu dengan sesuatu yang ada lainnya terpisah atau menyatu', 'apakah di luar sesuatu yang terlihat ada, adakah sesuatu yang ada lainnya', 'ketika suatu sudah dipastikan ada (terdefinisikan), apakah kepastiannya itu secara tersendiri atau ada pihak lain yang musti memastikan adanya' dan pertanyaan-pertanyaan metafisik lainnya. Sebab, jika pertanyaan tentang ada ini diabaikan, maka kajian tentang sesuatu itu sudah pasti tidak ada dan itu artinya penelitian ilmiah berhenti. Oleh karena itu, para filosof Muslim, sebagaimana Aristoteles menyebutnya sebagai The First Philosophy, menyebut metafisik ini dengan istilah al-falsafah al-ū $\overline{T a}$ atau meminjam istilah Ibn Sinā al-falsafah al-mutlaqah.

Tidak heran apabila kita menemunkan tema metafisik menyita banyak perhatian para filosof Muslim dengan berbagai isu yang melingkupinya. Sebut saja Hujjatul Islam al- Ghazzāli turun tangan mengkritisi problem-problem yang dianggap mengganggu. Dan tema- tema ini sampai hari ini masih berlanjut didiskusikan. Dalam tradisi Islam, para filosof, baik yang berlatar belakang filosof murni atau yang bergelar Mutakallim, Ușūii, Sufi dan lain sebagainya tidak ketinggalan mengkajinya hingga detail dengan berbaga1 ragam perbedaan penekanannya. Hanya saja, menyatukan berbagai latar belakang berfikir dalam suatu pandangan secara serasi bersama-sama dalam menyelesaikan problem-problem metafisis ini bukanlah persoalan sederhana, perlu usaha yang serius. Oleh karena itu, upaya penyatuan latar belakang pemikiran itu perlu diapresiasi sedalamdalamnya. Kajian ini adalah kajian metafisik yang menyatukan pandanganpandangan filosof Muslim, Mutakallim dan Sufi menurut filosof Melayu dekade ini, yaitu Sayyid Muhammad Naquib al-Attas.

\section{Biografi Singkat}

Sayyid Muhammad Naquib bin Ali bin Abdullah bin Muhsin al-Attas tahun 1931 lahir di Bogor, Jawa Barat. Putra dari pasangan Syed Ali alAttas (Johor Bahru, Malaysia) dan Sharifah Raguan al-Aydrus (Bogor, Jawa 
Barat Indonesia). ${ }^{1}$ Al-Attas lahir dari keluarga terhormat. Hal itu bisa dilihat dari beberapa sisi. Pertama, silsilah keluarganya bisa ditelusuri hingga sampai kepada Nabi Muhammad Saw. Ia keturunan ke 37 dari keturunan Husein r.a. Selain itu kakeknya juga dikenal seorang wali di Jawa dan neneknya juga merupakan saudara dari ratu Johor. ${ }^{2}$

Di lihat dari pendidikannya, al-Attas sejak usia lima tahun sudah menempuh sekolah dasar di Ngee Heng Primary School, thn 1936-1941, di Johor Bahru. Tahun 1941-1945 ia ia belajar bahasa Arab di Madrasah al'Urwat al-wuthqā, Suka Bumi, Jawa Barat. Tahun 1946-50 ia melanjutkan studi di Bukit Zahrah School di Johor dan kemudian di English College pada thn 1946-1951. ${ }^{3}$ Thn 1951, setelah menyelesaikan sekolah menengah pertama, al-Attas ikut serta dalam the Malay Regiment sebagai Cadet Officer no. 6675. Kemudian the General Sir Gerald Templer, the British High Commissioner of Malaya, memilihnya agar ikut pendidikan militer di Eton Hall, Chester, Wales, kemudian pada the Royal Military Academy, Sandhurst, England, tahun 1952-1955. ${ }^{4}$ Kemudian al-Attas mengundurkan diri dari King's Commission untuk bertugas di Royal Malay Regiment, meneruskan studinya di University of Malaya di Singapore, tahun 19571959. ${ }^{5}$ Di saat belajar di University of Malaya ini, dua buah karya dihasilkan, yaitu Rangkaian Ruba'iyyät dan Some aspects of Sufism as Understood and Practised Among the Malays. Dari buku kedua inilah kemudian pada thn 1959 dianugerahi fellowship dari Canada Council Fellowship untuk studi di Institute of Islamic Studies yang didirikan oleh Wilfred Cantwell Smith di McGill University in Montreal, Canada. Kemudian pada thn 1962, Al-Attas sudah menyelesaikan masternya dalam bidang filsafat Islam dengan nilai istimewa, dengan judul thesis Raniri and The Wujudiyyah of 17th Century Acheh, and awarded as a good work. ${ }^{6}$

Melihat produktifitas dan potensinya, maka kemudian beberapa orientalis seperti A.J. Arberry (Cambridge), Sir Mortimer Wheeler (British Academy), Sir Richard Winstedt (British Academy), President of Royal Asiatic Society, menasehatinya agar mentransfer studi doktoralnya ke

\footnotetext{
${ }^{1}$ Wan Mohd. Nor Wan Daud, The Educational Philosophy and Practice of Syed Muhammad Naquib Al-Attas: An Exposition of the Original Concept of Islamization (Kuala Lumpur: International Institute of Islamic Thought and Civilization [ISTAC], 1998), 1.

${ }^{2}$ Wan Mohd. Nor Wan Daud (1998), Op.Cit, 1.

${ }^{3}$ Ibid. 2-3.

${ }^{4}$ Ibid. 4.

${ }^{5}$ Ibid. 5.

${ }^{6}$ Lihat biografinya juga dalam Commemorative Volume on the Comferment of the AlGhazali Chair of Islamic Thought, Kuala Lumpur: International Institute of Islamic Thought and Civilization (ISTAC), 1994, 4.
} 
School of Oriental and African Studies (SOAS), University of London. Di kampus ini dia belajar dan bekerja pada Professor Arberry dan Dr. Martin Lings, thn $1965 .^{7}$ Di tahun yang sama ia lulus $\mathrm{PhD}$ nya dengan hasil yang memuaskan dengan dua volume tesis yang dihasilkan dengan judul The Mysticism of Hamzah Fansuri. ${ }^{8}$ Thn 1966 ia kembali ke UM dan ditunjuk sebagai Head of the Division of Literature di Department of Malay Studies, dan sebagai Dean of the Faculty of Arts di University yang sama, sejak 1968 hingga 1970. Al-Attas juga merupakan salah satu pioneer dan senior founder dari National University of Malaysia (UKM) yang berdiri pada 1970. Karya yang paling mengagungkan adalah ia sebagai penggagas, pendiri dan desainer International Institute of Islamic Thought and Civilization (ISTAC), baik dari segi arsitektur maupun kurikulumnya. ${ }^{9}$

Sementara sampai saat ini, karya-karya penting al-Attas adalah seperti: Rangkaian Ruba'iyāt (Kuala Lumpur: Dewan Bahasa dan Pustaka, 1959), Some Aspects of Sufism as Understood and Practised among the Malays (Singapore: Malaysian Sociological Research Institute, 1963), Raniri and the Wujudiyyah of the 17th Century Acheh(Kuala Lumpur: Monographs of the Malaysian Branch of the Royal Asiatic Society, 1969), The Mysticism of Hamzah Fansuri (Kuala Lumpur: University of Malaya Press, 1970), The Correct Date of the Terengganu Inscription (Kuala Lumpur: Museum Department, 1970), Islam dalam Sejarah dan Kebudayaan Melayu (Kuala Lumpur: Universiti Kebangsaan Malaysia, 1972), Comments on the Re-Examination of al-Raniri's Hujjat al-Siddiq: A Refutation (Kuala Lumpur: Museum Department, 1975), Islam and Secularism (Kuala Lumpur: Muslim Youth Movement of Malaysia [ABIM], 1978 and reprint, Kuala Lumpur: International Institute of Islamic Thought and Civilisation [ISTAC, 1993), The Concept of Education in Islam (Kuala Lumpur: ABIM, 1980 and reprint, Kuala Lumpur: ISTAC), A Commentary on the Hujjat al-Siddiq of Nür al-Dīn al-Rānirī: Being an Exposition the Salient Points of Distinction between the Positions of the Theologians, the Philosophers, the Sufis and the Pseudo-Sufis on the Ontological Relationship between God and the World and Related Questions (Kuala Lumpur: Malaysian Ministry of Culture, 1986), The Oldest Known Malay Manuscript: A 16th Century Malay Translation of the 'Aqa'’id of al-Nasafí

\footnotetext{
${ }^{7}$ Ibid. 4.

${ }^{8}$ Ibid. 5 .

${ }^{9}$ Wan Mohd. Nor Wan Daud (1991), Op.Cit. 4; ISTAC Illuminated (1998), Kuala Lumpur: ISTAC, 39; lihat juga Mona Abazah (2002), "S.N. Al-Attas: The Beacon on the Crest of A Hill or the Fusion of A Military Ethos with Science?", dalam Debates on Islam on Knowledge in Malaysia and Egypt, London: Routledge Curzon, 88.
} 
(Kuala Lumpur: University of Malaya, 1988), Islam and the Philosophy of Science(Kuala Lumpur: ISTAC, 1989) yang diterjemahkan ke bahasa Jerman oleh Christoph Marcinkowski dengan judul Islam und die Grundlagen von Wissenschaft, Kuala Lumpur: ISTAC, 2001), The Nature of Man and the Psychology of the Human Soul (Kuala Lumpur: ISTAC, 1990), On Quiddity and Essence (Kuala Lumpur: ISTAC, 1990), The Intuition of Existence (Kuala Lumpur: ISTAC, 1990), Islam: The Concept of Religion and the Foundation of Ethics and Morality (Kuala Lumpur: ISTAC, 1992), The Meaning and Experience of Happiness in Islam (diterjemahkan ke Bahasa Malaysia oleh Muhammad Zainiy Uthman dengan judul Makna Kebahagiaan dan Pengalamannya dalam Islam, Kuala Lumpur: ISTAC; dan ke dalam Bahasa Jerman oleh Christoph Marcinkowski dengan judul Die Bedeutung und das Erleben von Glückseligkeit im Islam, Kuala Lumpur: ISTAC, 1998), The Degrees of Existence, 1994, Prolegomena to the Metaphysics of Islam: An Exposition of the Fundamental Elements of the Worldview of Islam (Kuala Lumpur: ISTAC, 1995), Risalah untuk Kaum Muslimin (Kuala Lumpur: ISTAC, 2001), Tinjauan Ringkas Peri Ilmu dan Pandangan Alam (Penang, Malaysia: Universiti Sains Malaysia, 2007), Historical Fact and Fiction (Kuala Lumpur, Malaysia: UTM Press, 2011).

\section{"Hakikat" sebagai Basis Metafisik}

Sebagaimana diketahui, al-Attas merupakan salah satu ilmuan ahli filologi yang cukup disegani, terutama kajian atas manuskrip-manuskrip ulama Melayu sebelum masa penjajahan. Terlihat karya-karya filologisnya seperti atas karya Hamzah Fansuri, Nuruddin Raniri, akidah al-nasafi dan penyelesaian polemik penomeran pada Trengganu insciption. Sebagai ahli filologi, tentunya sangat teliti dalam penggunaan istilah-istilah, termasuk istilah-istilah seputar pemikiran dan filsafat Islam pada umumnya dan istilah metafisik pada khususnya. Oleh karena itu, untuk menghimpun konsepkonsep metafisiknya, mari kita mulai dengan istilah haq yang dari istilah ini nanti kita akan temukan istilah haqiq eksistensi, quidditi dan māhiyah.

Kata al-haq secara bahasa mengandung beberapa makna. Pertama, sebagai lawan kata bātil sebagaimana disebut dalam al-Qur'an bal naqdhifu bi al-ḥaqqi 'alā al-bațil. Kedua, sebagai salah satu nama penting dari namanama Allah Swt. yang suci. Ketiga, akurasi kata (șidq al-ḥadith). Keempat, yakin setelah ragu (al-yaqīn ba'da al-shak). Kelima, tetap (thābit). Keenam, dalam 'urf sebagai kesesuaian realitas (wāqi') dengan keyakinan (i'tiqād) sebagaimana kata sidq yang bermakna kesesuaian keyakinan 
dengan realitas. Dari itu, kata haqiqah bermakna 'sesuatu dalam penggunaannya ditempatkan sesuai dengan posisinya yang asal (mā uqirru fí alisti'māl 'alā asli wạ̣'ihî). Dengan makna ini maka kata haqiquah selaras dengan makna 'àdil, yaitu meletakkan sesuatu sesuai dengan tempatnya, konsisten (istiqāmah), tidak berlebihan (ifrat) dan tidak lalai(tafrit $).{ }^{10}$

Menarik untuk kita perhatikan, bahwa pandangan metafisik al-Attas bisa dikatakan berakar dari kata kunci haq ini. Maka tidak heran apabila dalam banyak kesempatan ia menyampaikan suatu statemen teologis Abū hafs al-Nasafî sebagai berikut: ${ }^{11}$

$$
\text { حقيقة الأشياء ثابتة والعلم مكا متحقق خلافا للسفسطائية }
$$

Bisa kita artikan dengan: "Hakikat segala sesuatu itu konstan, mengetahuinya adalah nyata, berbanding terbalik dengan golongan sofisme." Bagi al-Attas, statemen ini tidak saja teologis, tapi juga filosofis. Sebab dalam statemen ini meliputi isu-isu penting dalam filsafat, seperi esensi realitas segala sesutu (the essences of things), kemungkinan ilmu (the possibility of knowledge), tujuan ilmu (the objectivity of knowledge), dan sebab-sebab ilmu (the causes of knowledge). ${ }^{12}$

Fokus dengan bagian pertama, yaitu tentang hakikat segala sesuatu, maka bagi al-Attas kata haq itu mempunyai konsekuensi makna ontologis dan logis. Secara ontologis menggambarkan suaru realitas kewujudan (reality of existence), baik bentuk-bentuk dan aspek-aspeknya yang meliputi peristiwa-peristiwa dan proses-proses yang terjadi kepadanya. Sementara secara logis ia bermakna 'suatu hukum' yang berhadapan langsung dengan realitas-realitas eksternal yang muncul sebagai konsekuensi sesuatu (things) di luar peristiwa dan proses. Oleh karena itu, untuk menghasilkan sesuatu yang haq (truth, proper, thäbit) diperlukan "koresponden" antara intellectual act of judgement dengan external realities yang sudah dicerna oleh manusia secara "koheren". Di sinilah perlu mengetahui makna-makna sesuatu (haqīiqat al-ashyā'), sebagaimana statemen al-Nasafî̀ di atas, secara akurat melalui sumber ilmu yang tepat sehingga menghasilkan judgement yang adil. ${ }^{13}$ Tentu saja untuk seorang hakim, dalam hal ini para ahli hikmah, memerlukan pengetahuan tentang haqiqqat al-ashyā' secara komprehensif.

\footnotetext{
${ }^{10}$ Ali ibn Muhammad al-Sharāf al-Jurjānī, Kitāb al-Ta'rifăt (Beyrut: Maktabah Lubnan, 1985), 152.

${ }^{11}$ Lihat al-Attas, The Oldest Known Malay Manuscript: A 16th Century Malay Translation of Aqaid of al-Nasafi (Kuala Lumpur: Dept of Publication, University of Malaya, 1988).

${ }^{12}$ Lihat selanjutnya al-Attas, The Oldest Known Malay Manuscript: A $16^{\text {th }}$ Century Malay Translation of the 'Aqā'id of al-Nasafí (Kuala Lumpur: University of Malaya Press, 1988).

${ }^{13}$ Lihat Al-Attas, Prolegomena, 128-9.
} 
Dalam Filsafat al-Attas, yang beririsan langsung dengan tema haqiqat alashyā' ini adalah istilah-istilah seperti "Existence", "Quiddity", "Māhiyah" dan "Essence" sebagaimana biasa digunakan dalam istilah-istilah metafisik pada umumnya. ${ }^{14}$

Sebelum mengurai konsep metafisiknya secara detail, sebaiknya kita pahami posisi al-Attas di mana ia mempertegas posisinya sebagai seorang ilmuan Muslim yang tentu saja berbeda dengan ilmuan Barat modern. Ia menyatakan: ${ }^{15}$

"Our position is that what is truly descriptive of the fundamental nature of phenomena as process is 'existence' because existence alone, both understood as concept as well as a reality, is the most basic and universal entity known to us. It is true that existence understood as a concept is static and does not corresponda with process. But we maintain that existence is not merely a concept, it is also a reality: it is not merely posited in the mind, but is also a real and actual entity independent to the mind. It is dynamic, active, creative and pregnant with infinite possibilities of ontological selfexpression; it is an aspect of God that arises from the intrinsic nature of His names and attributes, and is therefore a 'conscious' entity acting in accordance with God's customary way of acting (sunnat Allah)."

Posisinya ini memperlihatkan suatu upaya memandang realitas dan kebenaran secara komprehensif, yang meliputi eksistensi yang paling rendah hingga eksistensi yang Maha Tinggi. Pandangan ini sudah sejak awal ia bangun melalui konsep Islamic Worldview-nya yang melihat bahwa Islam mempunyai cara pandang yang berbeda dan lebih komprehensif dibanding dengan cara pandang-cara pandang yang lain. Terlihat, dalam memformulasikan konsep metafisiknya ini, al-Attas mengkombinasikan tiga arus tradisi pemikiran Islam, yaitu tradisi Mutakallimīn, tradisi Failusuf Muslim dan tradisi Mutasawwifin, sebagaimana nanti kita urai lebih detail di bawah. ${ }^{16}$

\footnotetext{
${ }^{14}$ Ada semacam kritik terhadap penggunaan istilah-istilah ontologis yang digunakan al-Attas dalam On Quiddity and Essence oleh Syamsuddin Arif. Menurutnya, al-Attas dalam menjelaskan ontologi ini sering "shifts from a logical-philosophical perspective to ontologica 1-mystical viewpoint and vice versa".

${ }^{15}$ Al-Attas, Prolegomena, 128.

${ }^{16}$ Mengenai konsep Islamic Worldview nya ini bisa dilihat dalam pengantar prolegomena, $\mathrm{h}$. 1-39. Selain itu, konsep worldview islam secara lebih detail dan sistematik bisa dibaca dalam Alparslan Acikgence, Islamic Science: Towards A Definition (Kuala Lumpur: International Islamic Thought and Civilization [ISTAC], 1996); lihat juga makalah oleh Hamid Fahmy
} 
Tulisan ini akan lebih banyak merujuk kepada karyanya yang berjudul On Quiddity and Essence. Sebab karya ini adalah secara spesifik mengelaborasi konsep metafisiknya secara khusus. Namun demikian, sebagai sumber penopangnya akan dirujuk pula karya-karyanya yang lain.

\section{Eksistensi (Existence), Kuidditas (Quiddity) dan Esensi (Essence)}

Terlebih dahulu kita membahas problem istilah. Dalam On Quiddity and Essence menyebut beberapa istilah penting terkait metafizik seperti "existent" atau "being-existent" sebagai terjemahan dari bahasa Arab mawjūd. ${ }^{17}$ Sementara "Quiddity" adalah terjemahan dari bahasa Arab māhiyyah ${ }^{18}$ dan "essence" sebagai terjemahan dari bahasa Arab dhăt. ${ }^{19}$ Bagi para pemula dalam belajar filsafat (mubtadi'), tentu saja isitlah-istilah ini menimbulkan kebingungan, sebab mereka menggambarkan hal-hal abstrak dengan istilah yang mirip-mirip pemahamannya walaupun berbeda kenyataannya.

Lebih parah lagi ketika kita rujuk ke sumber-sumber berbahasa Inggris, di mana akan kita temukan istilah lainnya untuk terminologi ontologis ini. Misalnya kita temukan istilah "being" yang sering dipakai untuk menunjukkan kata "eksistensi". Padahal pada kenyataannya, kata "being" mempunyai makna beragam, sebagaimana dicontohkan oleh Syamsuddin Arif: "Being alone, I listened to music"; "I just hate being alone"; "I am a human being"; dan "Ontology deals with the problem of being”. Kalimat pertama, 'being' sebagai participle; 'being' kedua bermakna 'to be'; 'being ketiga, digunakan sebagai suatu kata benda yang merujuk kepada sesuatu yang real; dan yang keempat, digunakan sebagai konsepsi abstrak. $^{20}$

Begitu juga dalam bahasa Turki, di mana yang biasa dipakai untuk terminologi ontologis ini adalah kata "var". Namun demikian, kata "var" juga beragam penggunaannya yang bisa memicu kebingunan konsep. Contohnya saja: "Alemin yataratıcı vardır"; "Rahatsız etmek istemem, hem de işim var"; "Bu yolda bütün varını harcadı"; "Bir millet, varlığını, her şeyden çok dilinde yaşatır"; dan "Artık yaradılışının, var oluşun, hayatla ödüllendirilişinin sebebini bilmektedir". Kalimat pertama 'var' bermakna

Zarkasyi, Pandangan Hidup dan Tradisi Intelektual Islam: Eksposisi awal framework pemikiran Islam.

${ }_{17}^{17}$ Al-Attas, Prolegomena, 218 dan 236.

${ }^{18}$ Ibid: 219.

${ }^{19}$ Ibid. 236.

${ }^{20}$ Lihat makalah Syamsuddin Arif, "Being, Essence, and Quiddity: A Review Essay on Syed Muhammad Naquib al-Attas On Quiddity and Essence”, Kuala Lumpur, 1990. 
'mevcut, evrende veya düşüncede yer alan, yok karşıtı'; kalimat kedua bermakna 'sahıplik'; kalimat ketiga bermakna 'elde bulunan her şey'; dan kalimat keempat bermakna 'var olma durumu, mevcudiyet'. ${ }^{21}$ Oleh karena itu, mari melihat perbedaannya dalam diskursus filsafat dari beberapa bahasa (Yunani, Latin, English, Arab dan Turki), merujuk kepada skema yang dibuat Syamsuddin Arif dengan tambahan bahasa Turki, sebagaimana tabel berikut:

\begin{tabular}{|c|c|c|c|c|}
\hline Language & Infinitive & $\begin{array}{l}\text { Pr. } \\
\text { Participle }\end{array}$ & Noun & Keterangan \\
\hline Greek & $e l v \alpha l$ & $\omega v / o v \sigma \alpha$ & 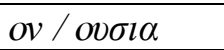 & \\
\hline \multirow{4}{*}{ Latin } & esse & essens & essentia & Hellenistic \\
\hline & esse & ens & entitas & Scholastic \\
\hline & esse & ens & entia & Later \\
\hline & existere & existens & existentia & \\
\hline \multirow{3}{*}{ English } & to be & being & beingness & \\
\hline & to exist & existing & existingness & \\
\hline & & existent & existence & \\
\hline \multirow{2}{*}{ Arabic } & wujida & mawjûd & mawjûdiyyah & \\
\hline & & & wujûd & \\
\hline \multirow{2}{*}{ Turkish } & var olmak & var olan & varlik & \\
\hline & & & varoluş & \\
\hline
\end{tabular}

Menurut Syamsuddin Arif, agar lebih memudahkan memahami tabel ini sebaiknya kita rujuk kepada karya St. Thomas Aquinas De Ente et Essentia, yang mana karya ini sering diklaim sebagai terjemahan Ontologi Ibn Sina versi bahasa Latin. ${ }^{22}$ Menurut Aquinas ${ }^{23}$ :

Esse = menunjukkan kepada aktifitas 'being' atau 'existing' (actus assedi)

Essentia = menunjukan sesuatu yang berlaku untuk semua hakekat yang berbeda antara satu hal dengan hal lainnya baik jenis partikulernya.

Ens = menunjukkan 'yang mana' (that which is) $=$ a being $=$ an existent $=\mathrm{a}$ concrete thing $=\mathrm{a}$ subject possessing in the act of being / existing (ens dicitur quasi esse habens).

\footnotetext{
${ }^{21}$ Lihat Türkçe Sözlük, Türk Dili Kurumu (TDK), tt,1550-1551.

${ }^{22}$ Syamsuddin Arif, Op.Cit. 1.

${ }^{23}$ Lihat Thomas Aquinas, On Being and Essence, tr. Armand Maurer (Toronto: Portifical Institute of Medieval Studies, 1983).
} 
Oleh karena itu, ketika esse menunjukkan 'the act of existing', maka itu artinya merupakan aktualitas atau aktualisasi (actuality/ actualization) dari pada essentia. Dengan kata lain, setiap ens adalah gabungan dari essentia dan esse:

$$
\begin{aligned}
& \text { Essentia }+ \text { Esse }=\text { Ens } \\
& \text { Essence }+ \text { to be }=\text { a being } \\
& \text { Essence }+ \text { existence }=\text { an existent } \\
& \text { Mahiyyah }+ \text { wujud }=\text { mawjud. }{ }^{24} \\
& \text { Varlık }+ \text { varolmak }=\text { bir Varlık. }{ }^{25}
\end{aligned}
$$

Oleh karena itu there is atau there exist adalah keberadaan individual yang konkret (a concrete individual existence) disebabkan essensinya, seperti "his being-a-man" atau "mannes" atau "humanity" yang dikatakan untuk istilah to be, to exist atau to actualize, di mana esensinya tidaklah konkret. Dengan demikian, ada yang mendasar antara kata "essence" dan "existence". ${ }^{26}$ Lalu bagaimana dengan kata "quiddity"?

Menurut al-Attas, kata "quidditas" merupakan istilah Latin yang menunjukkan "the distinctive nature or peculiarity of a thing". Menurutnya, istilah ini adalah terjemahan dari istilah Arab māhiyah. Kata māhiyah adalah kombinasi dari mā dan huwa/hiya, yang bermakna 'apa itu?' Oleh karena itu māhiyyah adalah sesuatu untuk jawaban 'mā hiya?' Sama dengan bahasa Latin quidditas adalah sesuatu untuk menjawab 'quid est?' menurutnya juga, istilah ini adalah kreasi folosof Muslim yang, barangkali, diadopsi dari suatu hadis yang berbunyi: Allāhumma arina al-ashyā' kamā hiya, yakni sesuatu sebagaimana dalam keaadaannya yang individual (things are in their individual whatness). ${ }^{27}$

Bisa disimpulkan bahwa penggunaan tiga istilah (existence, quidditty dan essence) di atas dalam filsafat metafisik al-Attas bermakna seperti berikut:

Existence $=$ kewujudan yang multi level.

Quidditi $\quad=$ yang menjawab pertanyaan apa dari segala yang eksis.

Essence $\quad=$ sesuatu yang sangat spesial dalam sesuatu yang eksis.

Sebagaimana disebutkan di atas bahwa konsep metafisik al-Attas merujuk pada pandangan para filosof Muslim, Mutakallim dan Sufi, maka akan kita temukan istilah-istilah yang mengkombinasi dari ketiga disiplin

\footnotetext{
${ }^{24}$ Syamsuddin Arif, Op.Cit. 2.

${ }^{25}$ Lihat Hüseyin Atay, Íbn Sina'da Varlık Nazariyesi (Ankara: Kültür Bakanlığı, 2001), 34.

${ }^{26}$ Syamsuddin Arif,Op.Cit. 2.

${ }^{27}$ Al-Attas, Op.Cit., hal. 219, footnote ke 236.
} 
ilmu itu dalam konsep metafiziknya. ${ }^{28}$ Hanya saja, sebagaimana disampaikan Syamsuddin Arif, dalam On Quiddity and Essence nya ini, walaupun al-Attas sering mengutip pendapat mutakallimin seperti alTaftazani, namun sayangnya seakan-akan al-Attas mengeliminasi isu-isu rumit Ilmu Kalam dalam isu metafisiknya ini (excludes the intricates Kalam theses on these issues). ${ }^{29}$ Oleh karena itu, pembahasan ini akan dipecah menjadi dua bagian: Logical philosophical perspective of metaphysic, ontological-mystical viewpoint dan bagaimana al-Attas mengkombinasikan keduanya dalam metafisik yang dipersepsikannya.

\section{Perspektif Logika Filosofis (Logical-Philosophical Perspective)}

Penjelasan metafisik al-Attas dari sudut pandang logika filosofis (logical-philosophical perspective) banyak mengikuti pola Ibn Sinā. AlAttas menguraikannya menjadi tiga pola penjelasan. Pertama, pembedaan antara quiddity dan existence dari segi bagaimana akal manusia mengabstraksi al-mawjū $\bar{u} \bar{t}$ dari tahap pertama sebagai al-ma'qūilàt al-ūla menuju tahap kedua yaitu al-ma'qūlät al-thāniyah. Kedua, quidditi dijabarkan dengan membedakan tiga ragam entitas dalam klasifikasi Ibn Sinā yang diistilahkan dengan: bishart là shay', lā bishart shay' dan bishart shay'. Ketiga, penguraian aspek ketiga dari quidditi (third aspect of quiddity). Lebih detailnya sebagaimana akan diuraikan di bawah ini.

\section{Quidditi dan Eksistensi}

Ketika kita ingin mengetahui makna realitas sesuatu (the meaning of reality) yang ada di luar diri kita (external world), maka mau tidak mau kita harus membedakan yang mana quidditi dan yang mana eksistensi. Kuidditas (whatness, māhiyah) adalah realitas sesuatu yang ada di luar diri kita yang bisa kita pahami oleh akal kita. Seperti kita memahami tentang 'manusia' yang ada di sekitar kita, maka tahap pertama adalah memahami realitas yang terkait dengan dunia fisiknya. Lalu kita sematkan kepadanya 'eksistensi'; bahwa manusia itu ada sebab kita telah mempersepsikannya. Namun yang kita persepsikan masih dalam tahapan pertama, di mana akal kita langsung berhadapan dengan dunia fisik. Dengan menyematkan 'eksistensi' kepada realitas pertama ini, maka kita berarti mengkualifikasinya (qualifies the quiddity). Oleh karena itu, seperti disebutkan al-Attas, dalam konteks ini, maka kuidditi itu adalah being

\footnotetext{
28 Adi setia, "Philosophy of Science of Syed Muhammad Naquib al-Attas", Islam and Science, vol. 1, No. 2, 165-215.

${ }^{29}$ Syamsuddin Arif, Op.Cit. 4.
} 
considered as the reality of a thing. Sementara eksistensi adalah being considered as qualifies the quiddity. ${ }^{30}$

Pada level ini quidditi bisa dikualifikasi dengan eksistensi mengikuti hukum fisik dunia luar. Namun pada level berikutnya, ketika pengabstrakan sudah mengendap dalam akal kita, maka hukum logikalah yang berlaku, bukan hukum ontologi lagi. Oleh karena itu, ada dua tahap pengabstrakan yang bisa diurai, yaitu tahap al-ma'qūlàt al-ūlà dan tahap al-ma'qūlàt althāní. Kedua-duanya adalah jenis-jenis sesuatu yang bisa dicerna akal yang biasa kita disebut dengan al-ma'qūlàt. Sesuai dengan akar katanya, yaitu 'aql yang bermakna mengikat, maka akal kita akan mengikat makna-makna yang sudah kita abstrak dari dunia luar dengan dua proses tersebut. ${ }^{31}$

Yang pertama bisa dipahami sebagai suatu informasi yang diabstrakkan oleh akal kita dari dunia luar (eksternal world), yakni dari luar akal kita (min khārij al-dhihn). Dari alam di sekitar kita itulah panca indera kita (al-khawās al-khams) mengabstrak atau menyerap imej-imej partikular (șürah juz'iyyyah) yang dikirim ke dunia dalaman (internal world) kita dan kemudian disimpannya. Betapa banyak informasi yang akal kita abstrak dari imej-imej yang dikirim dan disimpan tersebut setiap saat. Oleh karena itu, al-ma'qūlät yang pertama tidak bisa dipisahkan dari dunia luar kita. Ma'qūlāt tahap ini sebetulnya dunia luar itu sendiri, dunia fisik dan partikular. Ibn Sina biasa menyebutnya dengan al-a'yān al-mawjūdāt. Sebab, sebagaimana dijelaskan oleh Nasiruddin Țūsi, seorang murid dan sekaligus penafsir dari falsafah Ibn Sina, dunia luar itu bagi akal kita adalah sumber ilmu yang pertama (al-mașdar al-ūla). ${ }^{32}$ Sesuatu yang merupakan objek yang secara konkret ada di dunia eksternal yang berhubungan langsung dengan konsep yang diabstrak dari dunia luar itu. Al-Attas menerjemahkannya dengan "primary intellegible". 33

Sementara setelah informasi dari dunia luar itu disimpan di akal kita dan setelah terjadi proses konsepsi (tașawwur), maka ma'qūiàt pertama ini berubah menjadi ma'qūlāt kedua (al-ma'qūlāt al-thānî̀). Yakni, konsepkonsep yang terabstrak akan menjadi konsep-konsep yang kemudian terputus hubungannya dengan dunia luar. Jenis-jenis partikularnya (genus), macam-macamnya (species), perbedaan-perbedaannya (differentia), general dan umumnya (genere) dan khususnya (specific), pada tahap ini sudah bisa digunakan. Proses partikular menjadi general terjadi dalam benak kita secara

\footnotetext{
${ }^{30}$ Al-Attas, Op.Cit. 219.

${ }^{31}$ Lebih detail, lihat Al-Tahānawīi, Op.Cit., Jilid 2, 1194-1201.

32 İbn Sina, Al-Ishārāt wa al-Tanbīhāt (Beyrut: Muassasat al-Nu'man, tt), ed. Sulaıman Dunya, jilid 1, 118.

${ }^{33}$ Al-Attas, Op.Cit. 220.
} 
otomatis. Inilah yang biasa dikenal dengan kulliyyāt al-khams. ${ }^{34}$ Maka pada tahap ini akal kita sudah tidak lagi berhadapan langsung dengan dunia fisik, dunia eksternal atau dunia partikular, melainkan mengabstrak yang sudah ada yang tersimpan di akal. Oleh karena itu, tahap ini biasa disebut dengan al-ma'qūlāt al-thānî. Yaitu akal kita mempunyai kemampuan memproses data-data yang sudah tersimpan dalam benak kita secara logis dan otomatis menjadi konsep-konsep yang lebih abstrak dan kulli.

Dari konteks ini bisa dipahami bahwa realitas sesuatu, sebagaimana dipahami mengikuti the rules of logic and logical devisions (genus, species, and difference) yang semua itu merujuk kepada quidditi sebagai lawan dari eksistensi. Dalam hal ini quidditi dipahami sebagai realitas yang berbeda dan telah terkualifikasi secara konseptual dengan eksistensi. Oleh karena itu, hubungan quidditi dan eksistensi seperti hubungan subyek-predikat. Perspektif ini memunculkan pemahaman the nature of existence sebagai secondary intelligible yang tidak lagi berhubungan langsung dengan dunia luar (external world). ${ }^{35}$ Itu dari sisi pemahaman logis (logical understanding). Sementara dari sisi yang lain, quidditi bisa diurai dengan tiga level pemahaman ontologis (ontologically understood), sebagaimana akan dijelaskan dibawah ini.

\section{Quidditi: bishart lā shay', lā bishart shay' dan bishart shay'}

Ketika kita memahami quidditi sesuatu, itu artinya kita telah mengkonsepnya baik sesuatu itu sebagaimana eksis di dunia luar atau sebagaimana eksis di dalam akal. Oleh karena itu, sebenarnya, akal kita telah memahami hakekat quidditi itu sebagai yang mempunyai tiga aspek sekaligus, yaitu bishart lā shay', lā bishart shay' dan bishart shay'.

Bishart là shay', yaitu abstraksi murni (pure abstraction) yang tidak ada hubungannya dengan suatu yang lain atau tidak ada hubungannya dengan akal. Artinya, quidditi itu memang eksis secara ontologis, walaupun akal kita kemudian mengabstraknya. Tidak berhubungan dengan akal di sini maksudnya adalah tidak ada onyek spesifik dalam akal. Dengan kata lain akal kita tidak hadir kepada obyek partikular. Oleh karena itu, quidditi pada aspek ini adalah betul-betul independen dan tidak bisa dihubungkan kepada konsep-konsep lain. Konsep hewan (animal) sebagai dirinya sendiri, sebagai contoh, adalah tidak lain dan tidak bukan 'hewan' murni (pure animal) dan tidak bisa digabungkan (predicated) kepada konsep 'manusia', sebab manusia menunjukkan sesuatu yang lebih dari sekedar hewan murni (more

\footnotetext{
${ }^{34}$ Lihat Abdurrahman Hasan Jankah al-Maydani, Dawābiṭ al-Ma'rifah wa Ușūl al-Istidlâl wa al-Munazarah (Damaskus: Dar al-Qalam, 2008), 39.

${ }^{35}$ Al-Attas, Op.Cit. 220.
} 
than pure animal). Pada kondisi ini, yakni pada kondisi abstraksi murni, tidak ada konsep apapun yang bisa dikombinasikan dengannya untuk menghasilkan kesatuan makna (to form a meaningful unity). Sebab, kalau misalnya konsep 'rasional' ditambahkan kepada 'hewan' tersebut, maka tidak akan menghasilkan kombinasi yang kohern, karena 'hewan' adalah sebagai betul-betul hewan (pure animal) dan hewan murni tidak bisa dikualifikasikan dengan kerasionalan (cannot be qualified by rationality). ${ }^{36}$ Oleh karena itu, Ibn Sina menyebutnya dengan bishart là shay', yakni quidditi dalam bentuk materi (mâhiyyah-maddah) disyaratkan dengan tidak adanya hubungan dengan suatu apapun yang lain (bishart an là yakūna ma'ahū shay'). ${ }^{37}$

Là bishart shay', yaitu abstraksi terhadap quidditi yang tidak dibatasi oleh sarat 'ketidakterhubungan' kepada sesuatu, tapi bebas untuk mengikutsertakan dirinya dengan hal-hal individu lainnya. Seperti konsep 'hewan' pada aspek ini adalah berbicara quidditi yang tidak lagi terbatas kepada dirinya sendiri sebagai hewan murni (pure animal), tapi ada potensi untuk dipredikatkan kepada konsep-konsep lain dalam suatu kombinasi yang koheren. Contohnya, ketika konsep 'rasionalitas' dipredikatkan kepada 'hewan' di sini, maka akan menghasilkan suatu konsep 'manusia'. Maka 'hewan' di sini bisa menjadi predikat 'manusia', sebab 'kehewanan' dan 'kerasionalitasan' di sini adalah bagian-bagian yang konstituen dari manusia. ${ }^{38}$ Oleh karena itu, Ibn Sina menyebutnya dengan lā bishart shay'. Yakni tidak disyaratkan dengan harus tidak berhubungan dengan sesuatu ( $1 \bar{a}$ bishart an lā yakūna ma'ahü shay'). Inilah sebenarnya yang disebut māhiyah jinsiyyah (genus). ${ }^{39}$

Bishart shay', yaitu abstraksi terhadap quidditi sebagaimana pada $\bar{l} \bar{a}$ bishart shay' di atas dan hadir dalam akal kita. Ketika itu aksidensi seperti predikasi, universalitas, partikularitas dan hal-hal lain di mana aspek quidditi itu bercampur baur di dalamnya (mixed), sebagaimana 'hewan' merujuk kepada apa yang sudah eksis di dunia luar yang spesifik ditujukan kepada yang 'rasional'. Maka kata 'hewan' di sini spesifik merujuk kepada suatu obyek dunia luar yang merujuk kepada manusia tertentu. Oleh karena itu, ia mesti melekat kepada partikular dan oleh karenanya disebut spesies (species/naw'). ${ }^{40}$ Perlu dipahami bahwa banyak yang salah paham ketika menyebut manusia sebagai hewan hanya dipahami dari perspektif pure

\footnotetext{
${ }^{36}$ Ibid. 222.

${ }^{37}$ Ibn Sina, Ibn Sina, Op.Cit. 184.

${ }^{38}$ Al-Attas, Op.Cit. 222.

${ }^{39}$ Ibid. 222.

${ }^{40}$ Ibid. 222-223.
} 
animal sebagaimana aspek bishart lā shay', yaitu abstraksi murni. Padahal ketika menyebut al-insân hayawân al-nâtiq bukan berbicara hewan pada aspek itu, namun pada aspek yang là bishart shay' dan bishart shay'. Makanya hewan di sini biasa diterjemahkan dengan 'makhluk hidup' (living thing) yang diambil dari akar kata bahasa Arab hayyun.

Kombinasi logis amaupun ontologis dalam quidditi (al-māhiyah alnaw'iyyah) adalah esensi atau yang paling spesial dalam sesuatu. Sebab, menurut al-Attas, ia mengkombinasikan dua makna māhiyah, yang itu berarti sama dengan ketika kita mengatakan tentang realitas sesuatu yang merupakan sesuatu itu sendiri (huwa huwa). ${ }^{41}$

Tahap inilah yang al-Attas biasa sebut dengan istilah "realitas dan kebenaran" di mana terminologi yang pas dalam bahasa Arab, menurutnya, disebut haqiqah. Untuk mendukung pendiriannya ini, al-Attas mengutip statemen teologis al-Nasafi dalam kitab Aqāid-nya sebagaimana berikut: ${ }^{42}$

The reality of a thing (haqiqāt al-ashyā') and quiddity (māhiyyah) are that by which a thing is what it is (mä bih $\bar{i}$ al-ashyā' huwa huwa), like 'rational animal' with reference to 'man' in cotrast to 'laughing animal' and 'writing animal', since it is possible to conceive of 'man' without reference to them (i.e. laughing and writing) in as much as they are among the (category of) accidents (al-mawarid). And it may be said further that, that by which a thing is what it is, when considered (bi i'tibār) as being realized externally (tahaqqaqa), is an ipseity (huwiyyah); and when considered independently without considering them (i.e. its being realized and its being individualized), it is a quiddity. A 'thing' (al-ashya $\left.\bar{a}^{\prime}\right)$ according to us, is the existent (al-mawjüd); and subsistent (al-thubut); realization (al-tahaqquq); existence (al-wujūd); and coming-into-being (al-kawn) are synonymous terms, and the meaning of them is self evident. ${ }^{43}$

\section{Quidditi Aspek Ketiga (Third Aspect of Quiddity).}

Kombinasi logis maupun ontologis dalam quidditi (al-ms̄hiyah alnaw'iyyah) merupakan aspek ketiga, yang bagi al-Attas disebut dengan esensi. Baginya, aspek quidditi ketiga ini, sebagaimana al-Taftāzani rujuk kepada Ibn Sinā dalam komentarnya terhadap 'Aqīdah al-Nasafí sebagimana disebut di atas, adalah realitas-realitas sesuatu yang sudah paten (establish),

\footnotetext{
41 Ibid. 223.

42 Ibid. 224.

${ }^{43}$ Ibid. 224. Teks aslinya bisa dibaca dalam Taftazānī, Kelām İlmi ve İslām Akāidi: Şerhu'lakāid, Hazırlayan: Süleyman Uludağ (Dergâh Yayınları, İstanbul, 1999), 103.
} 
tidak berubah (thābitah). ${ }^{44}$ Sesuatu yang spesial yang merujuk kepada genus dan species ini adalah realitas sesuatu (haqiquat al-ashyā') dan quidditinya sekaligus yang hanya dipahami dalam konteks logika. Sebab, sebagaimana dicontohkan, kata 'hewan' saja bukanlah manusia, sebab menyebut hewan sama artinya dengan menyebut hakekat sesuatu tanpa adanya determinasi yang sepesial yang dimaksud dengan esesni. Begitu juga, menyebut 'rasional' saja bukanlah manusia, sebab yang rasional bisa jadi akan mencakup kepada selain manusia, seperti para malaikat dan lain sebagainya. Namun, ketika menyebut keduanya sekaligus ('hewan' dan 'rasional') muncullah kombinasi yang mendefinisikan manusia secara spesifik. ${ }^{45}$

Namun demikian, ketika menyebut 'manusia' dalam konteks quidditasnya, tidaklah secara otomatis bermakna kombinasi dari kedua hal itu (genus dan species). Sebab manusia tetaplah manusia. 'Kemanusiaan' (humanity) atau yang menjadikan manusia itu disebut manusia (being-man) atau dalam bahasa Arab disebut insāniyyah adalah ketika menyadari dalam dirinya sendiri bahwa ia bukanlah sejenis entitas yang sebagaimana umumnya. Hal itu karena, posisi bishart lā shay' juga berlaku kepada manusia itu sendiri yang tidak bisa disamakan dengan hewan dalam konteks sama-sama dalam level bishart lā shay'.

Hanya saja, ketika 'manusia' itu merujuk kepada suatu nama tertentu, seperti merujuk kepada Zayd, maka dengan cara yang sama ia juga bisa merujuk kepada Amr, yakni merujuk kepada seorang yang tunggal, individu yang eksis secara konkret (single, concretely existent individual). Namun demikian, 'kemanusian' atau yang menjadikan manusia menjadi manusia bukanlah yang ada di Zayd ataupun yang tidak ada di Zayd. Sebab kemanusiaan yang ada di Zayd dan yang tidak ada pada dirinya adalah pemosisian secara mental saja (mentally posited), pendeterminasian entitas yang disematkan kepada Zayd (attached), dalam satu sisi, dan tidak disematkan (not attached) kepadanya di sisi yang berbeda. ${ }^{46}$

Al-Attas menyatakan, bahwa tidak ada yang menjadikan manusia itu establish - baik juz'iyyah-nya, seprti 'rasional', sebagi contoh, ataupun yang aksidental ('ārị̣) kepadanya, seperti tertawa, sebagai contoh - kecuali yang sangat pribadi darinya, yaitu esesnsinya. Dalam kondisi seperi itu, manusia menjadi identitas baru yang bukan saja sekedar jiwa (soul) ataupun badan (body). Inilah yang disebut oleh al-Attas sebagai entitas ketiga (third entity). Entitas ketiga inilah yang bisa diekspresikan dengan kata "Saya". Ketika menyebut kata saya, sebenarnya ia ingin menunjukkan entitas ketiga

\footnotetext{
${ }^{44}$ Al-Attas, Op.Cit. 225; Al-'Aqâid, 16.

${ }^{45}$ Al-Attas, Op.Cit. 225.

${ }^{46}$ Ibid. 226.
} 
tersebut. Menurut Ibn Sina, kata "Saya" (Arabic: ana) adalah identitas jiwa manusia yang tidak merujuk kepada badan manusia. Kata itu merujuk kepada jiwa (soul). Dalam hal ini, Ibn Sina mengajukan alasan, pertama, "saya" terus menerus eksis (al-thābit al-mustamir), sementara badan akan berubah dan mati. Oleh karena itu, dengan pengertian ini, badan secara terus menerus mengalami "baru" dan tidak berlanjut. Padahal "saya" selalu berlanjut dalam semua tahapan usia jiwa itu. Badan sejak usia dini hingga dewasa terus mengalami perubahan. Namu itu tidak terjadi dengan "saya", sebab "saya" selalu eksis, selalu mengetahui apa yang terjadi di masa kecil dan dewasa dan seterusnya. Maka orang itu selalu menjadi "saya", walaupun badan boleh rusak. Kedua, "saya" mempunyai peran kesadaran (has role in awareness). Ketika seseorang memutuskan untuk melaksanakan sesuatu, seperti untuk belajar, menulis, mendengar, maka yang menyadarkan untuk bertindak dalam melakukan hal tersebut adalah "saya". Oleh karena itu, "saya" di sini mempunyai peranan terhadap diri manusia agar mengeksekusi suatu tindakan. Konsekuensinya, yang mempunyai aktifitas pada saat melaksanakan suatu aktifitas tersebut bukan sekedar badannya, tapi jiwanya. Ketiga, "saya" mempunyai kemampuan melaksanakan sesuatu yang tidak tunggal, tapi bisa banyak hal yang berbeda-beda dalam satu even dan waktu yang sama. Sementara badan tidak bisa melakukan hal-hal partikular secara terpisah-pisah waktu dan evennya. Sebagai contoh, "saya" bisa makan, minum, berfikir, mendengar, berjalan, di mana semua aktifitas itu bisa menyatu dalam diri "saya". Hanya "saya" yang bisa melakukannya, bukan badan. $^{47}$

Al-Attas menyatakan bahwa quidditi aspek ke tiga ini memang penggabungan, namun tidaklah gabungan itu sendiri. Dengan kata lain, ia sudah menjelma menjadi 'suatu yang ke tiga' secara mandiri, sebagaimana digambarkan dalam diagram berikut:

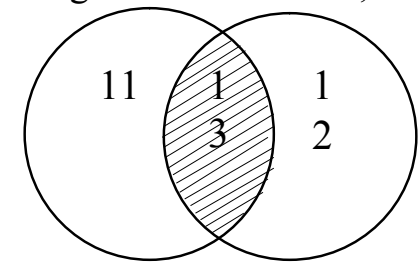

Dari diagram ini bisa dipahami, sebagaimana dijelaskan oleh al-Attas, dari sudut pandang logika, bahwa pada lingkaran pertama merepresentasikan jenis (genus) 'hewan' dan lingkaran kedua merepresentasikan pembeda (faşl) 'rasional', dan no 3 merepresentasikan spesies (naw') 'manusia'. Dengan

\footnotetext{
${ }^{47}$ Yohana Qamyar, Falāsifat al-'Arab: Ibn Sinā, (Beyrut: Dar al-Mashriq, Cet. Ke- 2, 1985), 37-39.
} 
pola yang sama dari sudut pandang ontologi bisa kita mengatakan, jika lingkaran 1 merepresentasikan bentuk materi (subtratum matter/madde) dan lingkaran 2 merepresentasikan bentuk substansi (substantial form/surah), maka no 3 semestinya merepresentasikan 'badan' sebagai substansi (jism). Begitu juga apabila no 1 merepresentasikan suatu komposisi badan (jism) yang mewujud dalam bentuk manusia (badan), dan no 2 merepresentasikan jiwa yang sensitif dan rasional (nafs), maka mestinya no 3 merepresentasikan seorang manusia (a human being). Oleh karena itu, realitas seorang manusia adalah yang paling khusus dari dirinya (the very self), bukan badannya ataupun jiwanya; bukan pula materinya ataupun bentuknya; dan bukan kehewanannya atau kerasionalitasannya. ${ }^{48}$

\section{Sebab-akibat dalam Quidditi}

Sebagaimana dijelaskan oleh al-Attas bahwa definisi realitas adalah mā bihì al-ashyā' huwa huwa, yang juga bisa diformulakan menjadi mā bihì al-shay' huwa huwa atau juga bisa diformulakan menjadi ma bihî huwa huwa, menunjukkan bahwa adanya huruf ba' dalam kata mâ bihî adanya penekanan sebab-akibat (sababiyyah) dalam definisi tersebut. Ini artinya, sesuatu menjadi sesuatu itu ada penyebabnya (sabab/'illah) yang mengantarkannya menjadi sesuatu. Penyebat ini bisa kita sebut dengan efficient cause (al-'illah al-fá'iliyyah) dan agen (al-fă'il). ${ }^{49}$

Sebagaimana dijelaskannya, tujuan mengetahui sebab sesuatu ('illat al-shay') adalah untuk mengetahui realitas sesuatu itu sendiri (haqiqah alshay'). Untuk mengetahui realitas sesuatu diperlukan mengetahui dua penyebab sekaligus, yaitu penyebab eksistensi (cause of existence/'illah alwujūd) dan penyebab quidditi (cause of quiddity/'illat al-māhiyah). Hal itu, menurutnya, sangat jelas terlihat dari penggunaan dua kata ganti ( $t w o$ personal pronoun/damirain) pada definisi quidditi di atas, yakni huwa huwa. Masing-masing merujuk kepada penyebab eksistensi (cause of existence) dan penyebab quidditi (cause of quiddity), yang mana keduanya secara bersama-sama menjadi penyebab sesuatu (cause of a thing). ${ }^{50}$

Menurutnya, keduanya merujuk kepada sesuatu wujud yang sama, yakni kepada substansi secara aktual sekaligus hakekat secara essensial. Oleh karena itu lebih detailnya, dua penyebab itu seperti berikut: Pertama, penyebab quidditi adalah kombinasi dari bagian-bagiannya (combination of its part) yang meliputi mental cause seperti jenis, perbedaan dan material cause seperti materi (maddah) dan rupa (form). Kedua, penyebab eksistensi

\footnotetext{
${ }^{48}$ Al-Attas, Op.C.it. 228.

${ }^{49}$ Ibid. 228.

${ }^{50}$ Ibid. 229.
} 
adalah agen aktif (active agent/al-fái), tujuan akhir (final purpose/alghāyah), dan subtraturm (al-mawḍ̂'). Lebih mudahnya, al-Attas memberikan diagramnya seperti berikut: ${ }^{51}$

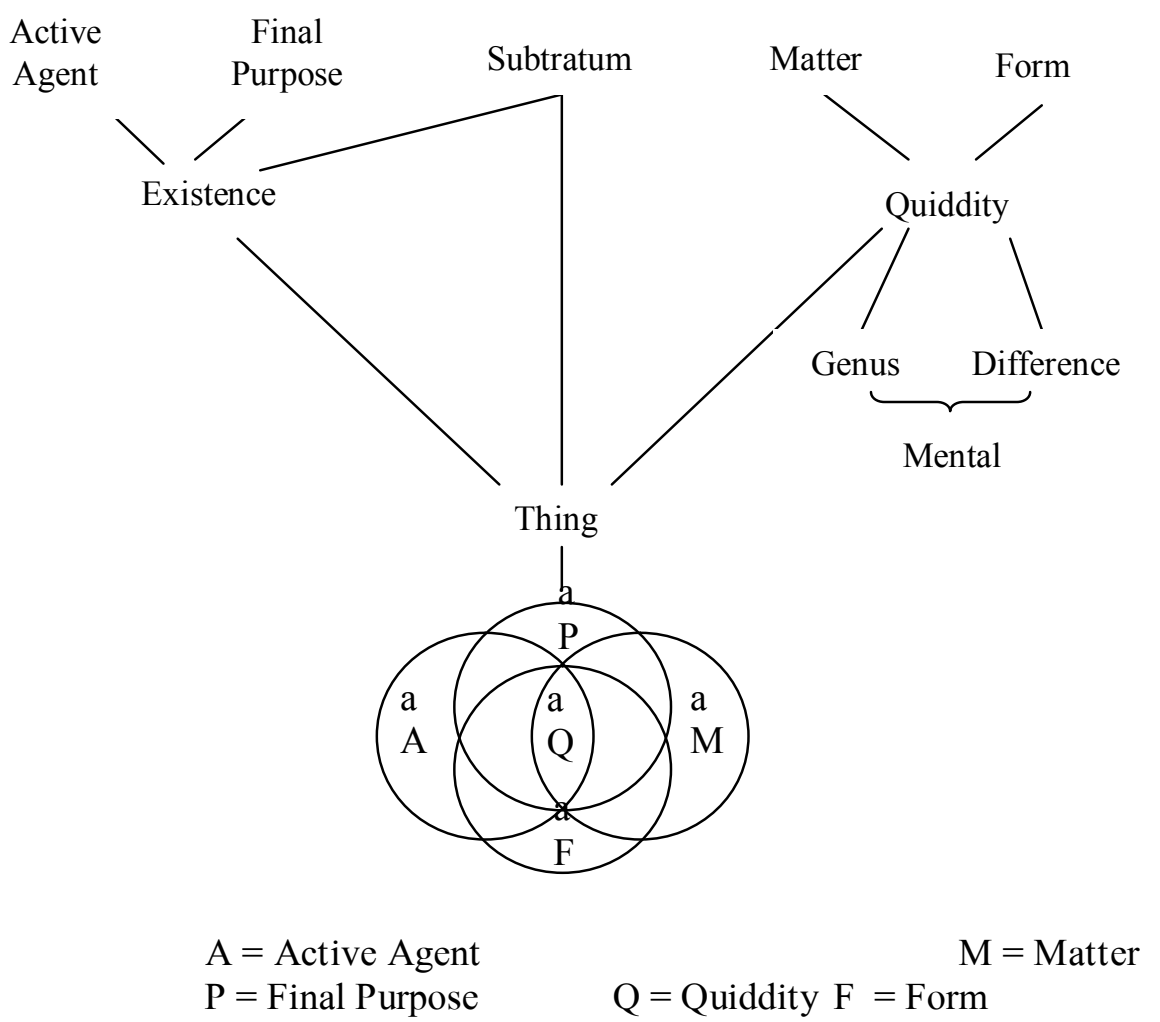

Jadi menurut al-Attas, berdasarkan skema di atas, di level konseptual, yaitu level akal, penyebab sesuatu terdiri dari dua hal, yaitu eksistensi dan quidditi. Namun di level aktual, hanya ada satu barang yang kongkret. Oleh karena itu, kata ganti yang terdapat pada definisi māhiyah di atas, yakni mā bihỉ al-shay' huwa huwa, yang pertama merujuk kepada quidditi dan yang kedua kepada eksistensi. ${ }^{52}$

Hukum kausalitas seperti di atas sudah dimaklumi luas di kalangan filosof yang diambil dari konsep kausalitas Aristoteles, bahwa dalam kausalitas ada empat macam, yaitu (1) effecient cause; (2) material cause; (3) formal cause; dan (4) final cause. ${ }^{53}$ Namun demikian, al-Attas tidak

${ }^{51}$ Ibid. 230.

${ }^{52}$ Ibid. 231.

${ }^{53}$ Muhittin Macit, "Meşşai Gelenekte Nedensellik”, İslami İlimler Dergisi, Y11 7, Cilt 7, Sayı

2, Güz 2012, 34. 
berhenti sampai di situ, sebab, sebagaimana al-GhazāTi, al-Attas berupaya menyambungkan kausalitas ini dengan penyebab utama, yaitu Allah SWT. Jika kita lihat hukum kausalitas dalam al-Ghazzāli, sebagaimana juga dipahami al-Attas, hukum kausalitas pada realitas fisik adalah sebagai bagian saja dari realitas metafisik. Bahkan realitas makhluk yang relatif itu tergantung kepada realitas metafisik yang mutlak. Pandangan metafisik yang demikian adalah pandangan metafisik kaum Sufi sebagaimana akan dijelaskan secara singkat di bawah ini. ${ }^{54}$

\section{Ontolojik-Mistik (Metafisik Kaum Sufi)}

Sebenarnya, metafisik yang telah kita bahas di atas, bagi al-Attas adalah bagian yang terendah dari pembahasan metafisik Islam. Sebab, di atas semua itu ada banyak hirarki metafisis yang berakhir pada kewujudan Sang Maha Wujud, Allah SWT. Ahli Sufi yang otentik dengan eksperimen yang mendalam mampu mencapai pengertian lalu menjelaskan realitas dan kebenaran (haqiqah) hirarki kewujudan tersebut dengan baik. Pencapaian hakikat mereka bukanlah sekedar pencapaian pemikiran semata. Di saat yang sama dengan menggunakan jalan intuisi, makna spiritual pun tercapai. Oleh karena itu, bagi al-Attas, intuisi sebagai saluran ilmu mempunyai peranan sangat penting dalam menyingkap (iktishäf) makna-makna dari setiap hirarki kewujudan tersebut.

Berdasarkan disiplin Tasawwuf Intelektual, ${ }^{55}$ al-Attas mencoba membina filsafat Islam yang otentik. Dengan tujuan ini, al-Attas mencoba membuat definisi tasawwuf yang ia anggap mampu merangkumi keperluankeperluan tasawwuf intelektual ini. Menurutnya Tasawwuf itu adalah "Pengamalan syariat di tingkatan Ihsan" (the practice of the shari'ah at the station of ihsan). ${ }^{56}$ Dengan kata lain, seorang Sufi sejati tetap berpijak kepada syariat dalam bertasawwuf. Definisi ini berdasarkan hadis yang diceritakan oleh Umar ibn al-Khațāab tentang suatu halaqah Nabi Muhammad Saw. dengan para sahabatnya yang didatangi Malaikat Jibril

\footnotetext{
54 Mengenai isu kausalitas Imam Ghazzali, lihat misalnya Hasan Ayık, "Gazāli ve Nedensellik Meselesi”, TYB Akademi, Ocak 2011.

55 Disebut tasawwuf intelektual demi menegaskan bahwa ada kalangan spiritualis yang kurang memperhatikan pentingnya ilmu dan menekankan hanya kepada aktifitas ruhiyah tanpa akliyah. Kebanyakan kaum Sufi yang demikian terjebak kepada tarekat yang cenderang mencetak Psedo-sufi atau Sufi yang bukan pencari hakikat sebenarnya. Mereka ini biasanya sering mengabaikan syariat dan terjebak dengan aktifitas ritual wirid yang berkepanjangan. Kaum sufi intelektual jauh dari yang demikian. Mereka mempraktikkan tasawwuf dengan ilmu yang agung.

56 El-Attas, The Positive Aspects of Tasawwuf: Preliminary thoughts on An Islamic Philosophy of Science, İslamic Academy of Science, Kuala Lumpur, 1981, s. 1.
} 
dan menanyakan kepada baginda Nabi tentang Islam, Iman dan Ihsan. ${ }^{57}$ Tiga level dalam agama ini, Islam menunjukkan level luar yang tampak atau bisa diistilahkan level syariat. Sementara iman adalah level batin yang tidak tampak. Sementara ihsan adalah level spiritual yang merangkumi level sebelumnya. Manakala seseorang menaiki level demi level, tidak semestinya diartikan meninggalkan level di bawahnya. Ketika orang beriman, bukan berarti kemudian meninggalkan Islam (syariat) nya. Sebab Iman tanpa Islam tidak mungkin sebab Islam adalah praktikal dari keimanan. Demikian juga Islam tanpa Iman adalah praktik yang tidak bermakna sebab ruh dari keislaman adalah keimanan. Demikian juga juga, ketika berada pada level Ihsan, maka dua level sebelumnya tidaklah ditinggalkan. Sebab fondasi keihsanan adalah keislaman dan keimanan. Tanpa fondasi yang kokoh, maka Ihsan mustahil tercapai. Oleh karena itu, definisi tasawwuf al-Attas adalah mempraktekkan syariat (tentu saja inklud keislaman dan keimanan) di tingkatan Ishsan. Dengan kata lain, meng-upgrade level sebelumya kepada kualitas yang ihsan. Kaum Sufi sejati adalah mereka yang berhasil melakukan upgrading ini, bukan mereka yang terjebak dalam ritualitas spiritual yang kosong dengan syariat. Tentu saja kaum Sufi otentik ini tidak meninggalkan sama sekali pencapaian intelektualitas ahli fikir Islam seperti filosof dan mutakallim yang menggunakan panca indera dan akal dalam mencapai ilmu, namun melakukan upgrading keduanya dengan intuisi. ${ }^{58}$

Ketika kaum Sufi otentik ini menyampaikan kebenaran (haqq), maka mereka merujuk kepada ilmu yang paling meyakinkan (Haq al-yaqin). Sebab mereka dengan kesadaran spiritual trans-empirik mengamati secara langsung hakikat fenomena-fenomena berbagai atau istilah lainnya kathrah (the Multiplicity of phenomena) dalam konteks realitas yang tunggal atau istila lainnya wihdah (in the Unity of the One Real Being) dan atau sebaliknya, mengamati realitas yang tunggal dalam konteks yang berbagai. Karena kemampuan mengamati langsung terhadap fenomena-fenomena tersebut maka kaum Sufi intelektual tidak pernah mengingkari semua kewujudan yang partikuler maupun yang plural. Sebab semua itu, mereka mengetahui level-level kewujudan itu serta dengan ilmu yang sejati selalu bersikap adil, tahu memposisikan diri dan memperlakukan apa yang diamati sesuai dengan kewajaran dan tepat perlakuan. Sebab, semua kewujudan yang tampak kepada para Sufi yang otentik ini adalah merupakan ta'ayyun dan tajalli

\footnotetext{
${ }^{57}$ Al-Imām Abū Zakariyyā Yahyā bin Sharaf al-Nawawī, Kitāb al-Arba'īn al-Nawawiyyah, (Kairo: Dar al-Salam, 2007), 4.

${ }^{58}$ Lihat juga Al-Attas, A Commentary on The Hujjat al-Siddiq of Nur al-Din al-Raniri, Ministry of Culture of Malaysia, Kuala Lumpur, 1986, 208-13.
} 
Allah Swt. yang mereka jumpai dengan jalan spiritual. Inilah yang sebenarnya yang biasa disebut Wahdāt al-Wujū oleh kalangan Sufi. ${ }^{59}$

Menurut al-Attas, Wahdāt al-Wujūd memperlihatkan sistem metafisik yang benar. Pandangan metafisik Wahdāt al-Wujūd ini merangkumi pemikiran ontolojik, kosmolojik dan psikolojik dalam Islam. Sebagaimana juga dijelaskan oleh al-Mahaimi, Wahdät al-Wujūd itu adalah "the unity of existence is that whereby things are actualized, and this is one" ${ }^{\prime 60}$ al-Attas memilih definisi ini untuk Wahdāt al-Wujūd. Dalam karya yang berjudul I⿳亠̣⿵h al-Maqșūd min Wahdāt al-Wujūd 'Abdul-Ghānì al-Nablusì (w. 1143/1733), mengatakan:

Vahdet-i vücûd'u benimsemekle Sufiler evrenin Tanrı ile aynı olduğunu kastetmediler. Çünkü Allah'ın varlığı zorunludur (vacibu'lcuvud). Evren ise mumkundur (mümkinu'l vucud), yani var-yok olan, başlangıç-bitiş olan şeylerdir. Mümkinatın varlığı sadece Vecibu'lcuvud'un taayyünatları ve tecelli -yetlerinin kanunlarını takip eder. $\mathrm{Bu}$ yüzden onların hiçbir ontik bağımsızlığı yoktur. Mümkün varlık sadece Yaratıcı'nın (Tek Gerçek Varlık) varlığıyla hareket eder. ${ }^{61}$

Tentang hubungan antara Pencipta dan ciptaan, dari sudut pandang rasional dan intuitif kebanyakannya mengikuti pandangan-pandangan Ibn Arabi. Dalam mengelaborasi metafisik dari sudut pandang tasawwuf, Ibn Arabi adalah yang paling detail. Sebagaimana diketahui, hubungan Sang Pencipta dengan ciptaan bisa dikenal dengan istilah tanazzul dan taraqqi. Yang pertama adalah dalam konteks tajalli wa ta'ayyun Sang Pencipta

\footnotetext{
59"Vahdet-i vücûd terimini meydana getiren kelimelerden vahdet (birlik), bazı metinlerde ahadiyyet yahut vahdâniyyetle birlikte zikredilerek "ahadiyyetü'l-vücûd" (vahdâniyyetü'lvücûd) şeklinde yer alır. Bulmak, bilmek anlamındaki vcd وجد) kökünden gelen "vücûd" terim olarak "varlık" anlamında kullanılır. Vücûd aynı kökten vecd ve tevâcüd ile bağlantılıdır. Muhyiddin İbnü'l-Arabî'nin en ulvî makamlara ulaşanlara atıf yaparken kullandığ1 "ehlü'l-keşf ve'l-vücud" (ehlü'l-cem' ve'l-vücûd) tabiri de vücûd terimindeki bu anlam bağlantısına işaret eder. Ehlü'l-keşf ve'l-vücûd tabiriyle hakikati keşf yoluyla bulan veya beşerîlikten soyutlanarak beka makamına ulaşanlar kastedilir. Bunun anlamı, varlığın hakikatinin ancak seyrüsülûk yoluyla beperîlikten tamamen soyutlanmak suretiyle idrak edileceğidir. el-Vücûdü'l-hak (gerçek/mutlak varlık) bu soyutlanma sürecinde hissî, aklî ve hayalî varlık biçimlerinden uzaklaşılarak idrak edilir. Abdülganī al-Nablusī, "Sâlikin en önemli görevi vücûdun anlamını tam olarak idrak etmektir" der, bunun da ancak fenâ makamına ulaşmakla mümkün olabileceğini belirtir. Sûfîlerin fenâ-beka nazariyesi de varlığı gerçekte idrak etmenin yöntemine iparet eder. Vücûdun ikinci anlamı "gerçek, gerçekteki" veya zihnin ve müşahedenin mukabili olarak "dıştaki” demektir. Bu durumda vahdet-i vücûdu iki şekilde anlamak mümkündür. Birincisi varlığın bir olması, ikincisi bu birliğın itibarî veya müşahedede değil dışta ve gerçekte bulunmasıdır.” TDV İslam Ansiklopedisi, Cilt. 42, 431.

${ }^{60}$ El-Attas, Op.Cit. 405.

${ }^{61}$ Nuh Ha Mim Keller, Reliance of the Traveller: A Classic Manual of Islamic Sacred Law, Amana Publications, Beltsville, Maryland, 1994, 1020 n. x5.
} 
kepada ciptaannya. Dengan kata lain, Sang Pencipta menampakkan ayatayat-Nya kepada hamba-hamba-Nya sesuai level dan martabat sang hamba. İni menggambarkan suatu hirarki kewujudan yang berawal dari Wujud Mutlak dan berakhir pada wujud mumkin yaitu wujud materi. Selengkapnya seperti berikut: ${ }^{62}$

1. Kesatuan Ilahi (al-Wāhidiyyah)

2. Nama-nama dan Sifat-sifat (al-Asmā' wa al-ṣifāt)

3. Arkitep Permanen (al-a'yan al-Thābitah)

4. Arketip-arkitep luar (al-a'yan al-Khärijiyyah)

5. Duniya yang tampak (Ālam al-Shahādah)

Sementara yang kedua, yaitu taraqqi, adalah kembalinya sang hamba kepada Sang Khāliq. Dengan kata lain, ketika manusia lebih tinggi mencapai derajat dan martabat (dengan cara ihsān / spiritual method), maka ia akan berjumpa dengan tajallīyāt dan ta'ayunāt Allah Swt. Jika seseorang mampu mencapai derajat dan martabat itu, maka ia akan melihat hakikat segala sesuatu dengan pengamatan langsung dan pencapaian informasi yang lebih akurat. Oleh karena itu, taraqqi di sini adalah upaya seseorang mengupgrade keilmuannya dengan cara ihsân. Tentu saja, tajalli dan ta'ayyun Allah SWT tidaklah tunggal. Sebagaimana al-Attas gambarkan di atas, paling tidak ada lima level ta'ayyun akan dijumpai oleh seseorang dalam mengenal Sang Pencipta. ${ }^{63}$

Ketika seseorang mencapai suatu level dengan ihsan, ilmu-ilmu yang asalnya didapat dengan panca indera dan akal tidaklah ditinggalkanö sebagaimana pengamalan ihsan tidak perlu meninggalkan syariat. Hanya saja, panca indera dan akal itu akan terupgrade menjadi instrumen spiritual yang biasa disebut dengan shuhūd, dhawq dan hudūr dalam istilah kaum Sufi. Oleh karena itu, pada level ihsan, sumber ilmu yang dipakai tidak sekedar sumber ilmu sebagaimana digunakan oleh filosof dan teologian, akan tetapi sudah ter-upgrade menjadi sumber-sumber ilmu spriritual yang lebih terpercaya dan akurat. ${ }^{64}$ Hakikat segala sesuatu (haqāiq al-ashyā') ada di dalam ilmu-ilmu Ilahi (in the Divine of Knowledge). Oleh karena itu, bagi manusia, ilmu-ilmu itu menjadi potensi untuk diketahui (isti'dāt ḥāliyyah). Inilah yang oleh kalangan Sufi disebut dengan Permanent Archetypes (ala'yān al-thābitah). ${ }^{65}$

\footnotetext{
${ }^{62}$ Lebih detail lihat al-Attas, Positive Aspect of Tasawwuf, 10-11; Prolegomena, 260, 267319, utamanyah, 274-80.

${ }^{63}$ Ibid. 260.

${ }^{64}$ El-Attas, The Positive Aspects of Tasawwuf, 8.

${ }^{65}$ El-Attas, Prolegomena, 12.
} 
Syed Muhammad Naquib al-Attas

Dan konsep metafisik dalam Islam

\section{Epilog}

Dalam pandangan al-Attas, metafisik dalam Islam tidaklah sekedar yang dipahami oleh para filosof dan ahli teologi. Tapi merupakan pencapaian hakikat baik yang hissi, aqIi dan intuisi plus wahyu sekaligus, dengan pengertian bahwa pencapaiannya ada di level ihsan. Baginya, ini adalah metafisik yang lebih menyeluruh. Sebab dengan demikian, hakikat segala sesuatu bisa dengan lebih sempurna diabstrak. Eksperimen dengan intuisi adalah eksperimen di tingkatan ihsan yang meng-upgrade level-level di bawahnya menjadi lebih terang dan akurat. Dari sudut pandang metafisik Islam ini, para Sufi yang otentik, buka Sufi yang palsu, adalah ilmuan sejati. Sebab merekalah yang langsung berinteraksi langsung dengan haqàiq alashyā', yang menyimpan makna, hikmah dengan martabat masing-masing yang menuntut untuk diperlakukan sewajarnya sesuai dengan tuntutannya. Pandangan spiritual inilah yang menjadi framework dari seluruh pemikiran al-Attas yang digaungkannya dengan istilah "Worldview Islam". Oleh karena itu, pada posisi itulah yang membedakan al-Attas dengan ilmuanilmuan lain dalam metafisik terutama jika dihadapkan dengan posisi ilmuanilmuan Barat sebagaimana ia banyak mengkritisinya. Tentu saja al-Attas tidak seratus persen membuat atau mengkonsep baru konsep metafisiknya. Ia meramu ulang tradisi keilmuan Islam yang sudah ada sebelumnya seperti tradisi filsafat, kalam dan tasawwuf. Sehingga dari hasil racik ulang tradisitradisi keilmuan Islam sebelumnya itu melahirkan framework metafisis yang dianggap lebih menyeluruh.

\section{Daftar Pustaka}

Abazah, Mona. Debates on Islam on Knowledge in Malaysia and Egypt, London, Routledge Curzon, 2002.

Aquinas, Thomas. On Being and Essence, trc. Armand Maurer, Toronto, Portifical Institute of Medieval Studies, 1983.

Arif, Syamsuddin. "Being, Essence, and Quiddity: A Review Essay on Syed Muhammad Naquib al-Attas On Quiddity and Essence", bir mekale, Kuala Lumpur, ISTAC, 1990.

Al-Attas, Syed Muhammed Naquib, A Commentary on The Hujjat AlSiddiq of Nur al-Din al-Raniri, Kuala Lumpur, Ministry of Culture of Malaysia, 1986.

. Prolegomena to the Metaphysics of Islam: An Exposition of the Fundamental Elements of the Worldview of Islam, Kuala Lumpur, ISTAC, 2001. 
. The Oldest Known Malay Manuscript: A 16th Century Malay Translation of Aqaid of al-Nasafi, Kuala Lumpur, Dept of Publication, University of Malaya, 1988.

. The Positive Aspects of Tasawwuf: Preliminary thoughts on An İslamic Philosophy of Science, Kuala Lumpur, İslamic Academy of Science, 1981.

Atay, Hüseyin. İbn Sina’da Varlık Nazariyesi, Ankara, Kültür Bakanlığı, 2001.

Ayık, Hasan, "Gazāli ve Nedensellik Meselesi", TYB Akademi, Ocak 2011.

Benovsky, Jiri. "The bundle theory and the substratum theory: deadly enemies or twin brothers?" Springer Science+Business Media B.V, 2007.

Commemorative Volume on the Comferment of the Al-Ghazali Chair of Islamic Thought, Kuala Lumpur, International Institute of Islamic Thought and Civilization (ISTAC), 1994.

Dawud, Wan Mohd. Nor Wan, The Educational Philosophy and Practice of Syed Muhammad Naquib Al-Attas: An Exposition of the Original Concept of Islamization, Kuala Lumpur, International Institute of Islamic Thought and Civilization [ISTAC], 1998.

Al-Ifrikī, Ibn Manzūur. Lisān al-'Arab, Beyrut, Dār Sadr, 1990.

ISTAC Illuminated, Kuala Lumpur, IST AC, 1998.

Islam Ansiklopedisi, Ankara, Türkiye Diyanet Vaktfı, 2003.

Al-Jurjānī, Ali b. Muhammed al-Sharif. Kitab al-ta'rifāt, Beyrut, Mektaba Lubnan, 1981.

Keller, Nuh Ha Mim. Reliance of the Traveller: A Classic Manual of Islamic Sacred Law, Beltsville, Maryland, Amana Publications, 1994.

Macit, Muhittin, "Meşşai Gelenekte Nedensellik", İslami İlimler Dergisi, Y11 7, Cilt 7, Sayı 2, Güz 2012.

Al-Maydānī, Abdurrahmān Hasan Jankah. Dawābit al-Ma'rifah wa Ușūl alIstidlāl wa al-Munāzarah, Damaskus, Dār al-Kalām, 2008.

Al-Nawawī, al-Imām Abū Zakariyyā Yahyā bin Sharaf. Kitāb al-Arba'īn alNawawiyyah, Kairo, Dār al-Salām, 2007.

Qamyar, Yohana. Falāsifāt al-'Arab: Ibn Sīnā, Beyrut, Dār al-Mashriq, 1985.

Sinā, Ibnu. al-Ishārāt wa al- Tanbīhāt, ed. Suleyman Dunya, Beyrut, Muassasah al-Nu'mān.

Taftazānī. Kalām İlmi ve İslām Akāidi: Şerhu'l-akāid, Hazırlayan: Süleyman Uludağ, İstanbul, Dergâh Yayınları, 1999.

Tahānawī, Muhammad Ali. Kashshāf Istilāhāt al-Funūn, Beyrut, Maktaba Nashirun, 1996. 
Türkçe Sözlük, Ankara, Atatürk Kültür, Dil ve Tarih Yüksek Kurumu (TDK), 2011.

Zarkasyi, Hamid Fahmy. "Pandangan Hidup dan Tradisi Intelektual Islam: Eksposisi awal framework pemikiran Islam.”Makalah. 